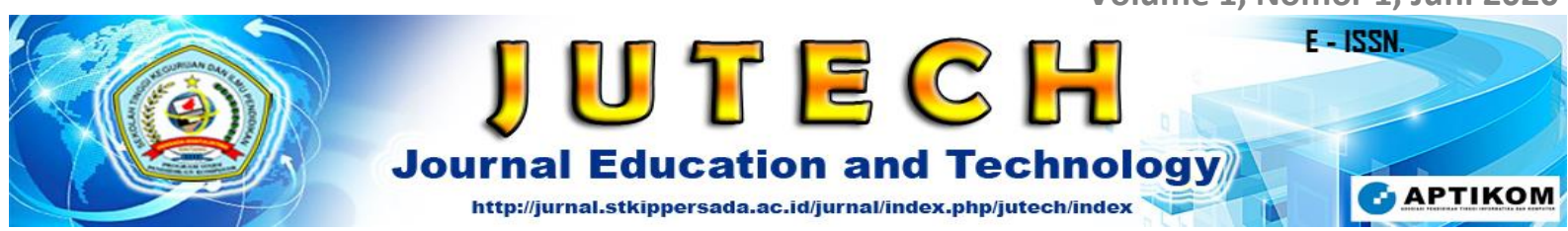

\title{
UPAYA MENINGKATKAN HASIL BELAJAR MENGGUNAKAN MEDIA PEMBELAJARAN INFORMATION AND COMMUNICATION TECHNOLOGIES (ICT)
}

\author{
Oktavianus $^{1}$, Yusuf Olang ${ }^{2}$, Fatkhan Amirul Huda ${ }^{3}$ \\ ${ }^{1}$ Program Studi Pendidikan Guru Sekolah Dasar STKIP Persada Khatulistiwa Sintang \\ ${ }^{2}$ Program Studi Pendidikan Bahasa dan Sastra Indonesia STKIP Persada Khatulistiwa Sintang \\ ${ }^{3}$ Program Studi Pendidikan Komputer STKIP Persada Khatulistiwa Sintang \\ email : abcdbharata@yahoo.com, yusufolang@yahoo.com, fatkhanamirulhuda@gmail.com
}

\section{Informasi Artikel}

Riwayat artikel :

Disubmit : 23 April 2020

Direvisi : 10 Mei 2020

Diterima : 16 Mei 2020

Dipublikasi : Juni 2020

Keywords:

Study Result, The Media

Impornation and

Communication

Technologies ( ICT)

Kata Kunci:

Hasil Belajar, Media

Information and

Communication

Technologies (ICT)

\section{ABSTRACT}

The purpose of this study is to imporove student learning outcomes with the use of media impormation and communication technologies ( ICT) on kind visible nature and make in indonesia on class V element of SD Joseph Khatulistiwa lesson year 2017/2018. The research method and the research form in classroom action research (PTK). The subjects of this research are the student of grade V SD Joseph Khatulistiwa. Data collection tool in this research is observation sheet, interview guide, test sheet and documentation. The results of the study found that the use of media impormation and communication technologies (ICT) outcomes, where student are seen to have enthusiasm and good cooperation in learning the improvement of students learning outcomes kusing media impormation and communication technologies (ICT) in gradev V of SD Joseph Khatulistiwa. Is categorized very well. it can be seen from the improvement of learning result achievement 33,33\%, that is from $55,56 \%$ I cycle to $88.89 \%$ in cycle II. based on the matter, it can be conduded that the learning media impormation and communication technologies (ICT) able to increase student learning outcomes on the material kind visible nature and make in indonesia in class V SD Joseph Khatulistiwa lesson year 2017/2018.

\section{ABSTRAK}

Tujuan dari penelitian ini adalah untuk meningkatkan hasil belajar siswa dengan menggunakan media pembelajaran information and communication technologies (ICT) pada materi keragaman kenampakan alam dan buatan di Indonesia di kelas V SD Joseph Khatulistiwa Tahun Pelajaran 2017/2018. Metode penelitian yang digunakan dalam penelitian ini adalah penelitian kualitatif dan bentuk penelitiannya Penelitian Tindakan Kelas (PTK). Subjek penelitian adalah siswa kelas V SD Joseph Khatulistiwa. Alat pengumpul data dalam penelitian ini adalah lembar observasi, pedoman wawancara, lembar tes, dan dokumentasi. Hasil penelitian ditemukan bahwa penggunaan media Informtion and Communication Technologies (ICT) di kelas V SD Josep Khatulistiwa dapat meningkatkan hasil belajar siswa, dimana siswa terlihat memiliki semangat, dan antusias serta kerja sama yang sangat baik dalam pembelajaran. Peningkatan hasil belajar siswa menggunakan media pembelajaran Information and Comminication Technologies (ICT) di kelas V SD Joseph Khatulistiwa dikategorikan sangat baik, hal ini dapat dilihat dari peningkatan ketuntasan hasil belajar sebesar $44,44 \%$, yakni dari siklus I 55,56\% menjadi $88,89 \%$ pada siklus II. 


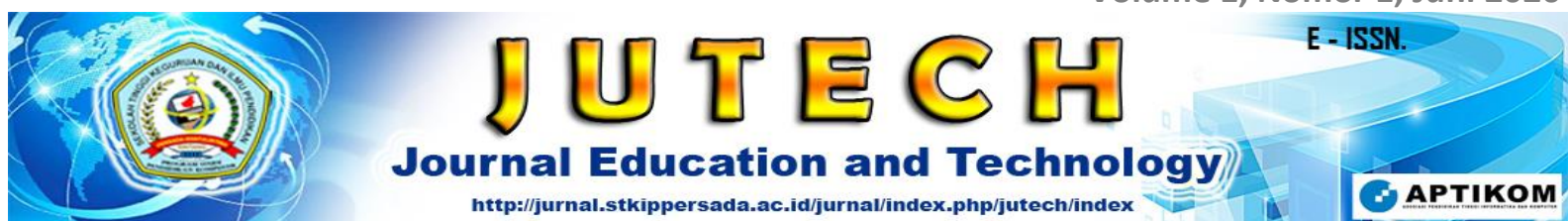

Berdasarkan hal tersebut maka dapat disimpulkan bahwa penggunaan media Information and Communication Technologies (ICT) mampu meningkatkan hasil belajar siswa pada materi keragaman kenampakan alam dan buatan di Indonesia pada kelas V SD Jseph Khatulistiwa Tahun Pelajaran 2017/2018.

\section{PENDAHULUAN}

Pendidikan pada hakikatnya adalah usaha membudayakan manusia atau memanusiakan manusia. Dengan kata lain, usaha agar manusia dapat mengembangkan potensi dirinya melalui proses pembelajaran atau dengan cara lain yang dikenal dan diakui oleh masyarakat. Hal ini seperti yang telah dituangkan dalam Undang-Undang Nomor 20 Tahun 2003 tentang sistem Pendidikan Nasional menyatakan bahwa pembelajaran merupakan seperangkat tindakan yang dirancang untuk mendukung proses belajar peserta didik, dengan memperhitungkan kejadian-kejadian eksternal yang berperan terhadap rangkaian kejadian-kejadian internal yang berlangsung di dalam diri peserta didik.

Ahmad (2012:7) menyatakan, bahwa "istilah pembelajaran dalam khazanah ilmu pendidikan, sering disebut juga dengan pengajaran atau proses belajar mengajar. Dalam bahasa inggris disebut dengan teaching atau teaching and learning”. Maka dapat disimpulkan bahwa pembelajaran adalah segala upaya yang dilakukan oleh guru (pendidik) agar terjadi proses belajar pada diri siswa. Secara implisit, didalam pembelajaran ada kegiatan memilih, menetapkan dan mengembangkan metode untuk mencapai hasil pembelajaran yang diinginkan. Pembelajaran lebih menekankan pada caracara untuk mencapai tujuan dan berkaitan dengan bagaimana cara mengorganisasikan materi pelajaran, menyampaikan materi pelajaran, dan mengelola pembelajaran.

Proses pembelajaran yang terjadi dalam dunia pendidikan adalah proses interaksi antara Guru dan Siswa serta siswa dan siswa. Berhasil tidaknya proses pembelajaran berhubungan dengan bagaimana interaksi antara Guru dan Siswa serta siswa dan siswa tersebut. Interaksi yang dibangun merupakan usaha yang dilakukan oleh seorang Guru untuk mendapatkan umpan balik dari siswa dalam pola pembelajaran. Dalam pembelajaran itu sendiri seorang Guru harus mampu menghidupkan motivasi siswa dalam belajar baik melalui cara mengelola kelas dan cara mengajar pada semua mata pelajaran. 
Belajar aktif sangat diperlukan oleh peserta didik untuk mendapatkan hasil belajar yang maksimal. Ketika peserta didik pasif, atau hanya menerima dari pengajar, ada kemungkinan untuk cepat melupakan apa yang telah diberikan. Oleh sebab itu, diperlukan perangkat tertentu untuk dapat mengikat informasi yang baru saja yang di terima dari guru. Belajar aktif adalah salah satu cara untuk mengikat informasi yang baru kemudian menyimpannya di dalam otak. Belajar yang hanya mengandalkan indra pendengaran mempunyai beberapa kelemahan, padahal hasil belajar disimpan hingga waktu yang lama. Filosof Cina, Confisius mengatakan:

What i hear, iforget

What i see, i remember, and

\section{What $i$ do, $i$ understand}

Apa yang saya dengar, saya lupa

Apa yang saya lihat, saya ingat, dan

Apa yang saya lakukan, saya memahami

ICT adalah sebuah payung besar terminoligi yang mencakup seluruh peralatan teknis untuk memproses dan menyampaikan informasi. ICT mencakup dua aspek, yaitu teknologi informasi dan teknologi komunikasi. Teknologi informasi meliputi segala hal yang berkaitan dengan proses, penggunaan sebagai alat bantu, manipulasi, dan pengelolaan informasi.
Sedangkan teknologi komunikasi adalah segala sesuatu yang berkaitan dengan penggunaan alat bantu untuk memproses dan mentrasfer data dari perangkat yang satu ke lainnya.Oleh karena itu, teknologi informasi dan teknologi komunikasi adalah dua buah konsep yang tidak terpisahkan. Jadi, ICT mengandung pengertian luas, yaitu segala kegiatan yang terkait dengan pemprosesan, manipulasi,pengelolaan, pemindahan informasi antarmedia.

Ilmu pengetahuan sosial merupakan pengetahuan mengenai segala sesuatu yang berhubungan dengan masyarakat. Di Indonesia pelajaran ilmu pengetahuan sosial disesuaikan dengan berbagai prespektif sosial yang berkembang di masyarakat. Kajian tentang masyarakat dalam Ilmu Pengetahuan Sosial dapat dilakukan dalam lingkungan yang terbatas, yaitu lingkungan sekitar sekolah atau siswa dan siswi atau dalam lingkungan yang luas, yaitu lingkungan negara lain, baik yang ada di masa sekarang maupun di masa lampau.

Pembelajaran yang melibatkan peran siswa secara aktif dalam kegiatan belajar mengajar. Pembelajaran tersebut juga harus dapat meningkatkan pemahaman siswa pada materi sehingga hasil belajar pun meningkat. Salah satu media pembelajaran yang dapat meningkatkan hasil belajar 
siswa adalah dengan menggunakan media pembelajaran ICT. Sehubungan dengan hal tersebut di atas jelas bahwa pelajaran IPS menujang kemajuan perkembangan teknologi. Keberhasilan pengajaran Ilmu Pengetahuan Sosial ditentukan oleh berbagai hal antara lain, kemampuan siswa dan kemampuan guru itu sendiri di dalam melaksanakan proses belajar mengajar yang bermakna sesuai dengan tujuan pengajaran ilmu pengetahuan sosial. Siswa sebagai objek pengajaran, memiliki memampuan yang berbeda-beda, ada yang cerdas dan ada pula yang kurang. Oleh karena itu, seorang guru harus pandai dalam memilih atau menyampaikan materi kepada siswa dengan melihat metode atau media yang ada karena keragaman yang ada pada siswa.

Pembelajaran yang lebih mengandalkan metode ceramah membuat siswa menjadi bosan dan kurang aktif dalam preses belajar mengajar. Mata pelajaran IPS juga masih dianggap sebagai mata pelajaran yang menuntut kemampuan menghafal tanpa perlu upaya pemahaman dan dikaitkan dengan permasalahan kehidupan sehari-hari.

Berdasarkan hasil observasi peneliti pada tanggal 11 Maret 2017 di SD Joseph Khatulistiwa, hasil wawancara peneliti dengan guru kelas $\mathrm{V}$ mengatakan bahwa siswa-siswi kesulitan untuk menerima materi pelajaran, khususnya dalam pembelajaran IPS. Hal ini kemudian berpengaruh pada rendahnya hasil belajar siswa dalam pembelajaran tersebut. Pernyataan ini dibuktikan dengan rendahnya nilai ulangan siswa pada mata pelajaran IPS tahun pelajaran 2016/2017 ternyata hasil ulangan dari 9 siswa hanya 4 siswa yang tuntas atau $40 \%$ dan siswa yang tidak tuntas berjumlah 5 siswa atau $60 \%$, sementara kriteria ketuntasan minimal (KKM) untuk mata pelajaran IPS adalah 60. Selain itu, dalam wawancara penulis dengan guru kelas VSD Joseph Khatulistiwa diperoleh informasi bahwa pada proses pembelajaran siswa cenderung kurang aktif dan sulit untuk menyampaikan pertanyaan dan pendapat sehingga dalam pembelajaran kurang terjadi interaksi umpan balik yang dapat memicu pemahaman siswa terhadap materi pelajaran hasil ini menjadi tantangan bagi seorang guru untuk bisa mengeluarkan kemampuan dalam diri siswa dalam mencapai hasil belajar.

Salah satu solusi yang dapat dilakukan guru untuk mengatasi masalah tersebut adalah dengan mengembangkan strategi pembelajaran yang digunakan dalam proses pembelajaran. Media 


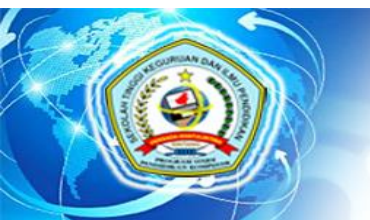

\section{DERECH Journal Education and Technology}

E-ISSN.

http://jurnal.stkippersada.ac.id/jurnal/index.php/jutech/index

pembelajaran yang memungkinkan dapat meningkatkan hasil belajar siswa dan salah satu yang dimaksud dalam hal ini adalah media pembelajaran information and communication technologies (ICT). Oleh karena itu penulis meneliti tentang Upaya Meningkatkan Hasil Belajar Keragamanan Kenampakan Alam dan Buatan di Indonesia Menggunakan Media Pembelajaran Information and Communication Technologies Pada Siswa Kelas V SD Joseph Khatilistiwa Tahun Pelajaran 2017/2018.

\section{METODE PENELITIAN}

Menurut Sugiyono (2013:2) metode penelitian pada dasarnya merupakan cara ilmiah untuk mendapatkan data dengan tujuan dan kegunaan tertentu . Metode yang digunakan dalam penelitian ini yaitu penelitian kualitatif. Karena data kualitatif disajikan dalam bentuk pernyataan katakata atau gambaran tentang sesuatu yang dinyatankan dalam bentuk penjelasan dengan kata-kata atau tulisan.

Peneliti memilih metode penelitian deskriftif kualitatif karena dalam penelitian ini penulis mendeskripsikan keadaan mengenai "upaya meningkatkan hasil belajar keragaman kenampakan alam dan buatan di Indonesia menggunakan media
Pembelajaran information and communication technologies (ICT) pada siswa kelas V SD Joseph Khatulistiwa tahun pelajaran 2017/2018.

Bentuk penelitian yang dilaksanakan adalah Penelitian Tindakan Kelas (Class Room Action Research). penelitian tindakan kelas merupakan bentuk penelitian reflektif yang dilakukan oleh peneliti sendiri yang hasilnya dapat dimanfaatkan dan dapat berguna sebagai alat untuk perkembangan sekolah, perkembangan kurikulum, perkembangan keahlian mengajar dan sebagainya”. Dengan melaksanakan PTK peneliti akan terjun langsung ke dalam suasana pembelajaran yang sesungguhnya, sehingga dapat memahami segala kemungkinan yang akan terjadi di dalam kelas. Selain itu, dengan melaksanakan PTK peneliti akan merasakan bagaimana rasanya menjadi seorang guru yang sesungguhnya. Sedangkan Kunandar (2008:46) mengemukakan bahwa Penelitian Tindakan Kelas adalah penelitian untuk membantu seseorang dalam mengatasi secara praktek personal yang dihadapi dalam situasi darurat dan membantu pencapaian Ilmu Pengetahuan Sosial dengan kerja sama dalam kerangka etika yang disepakati bersama. 


\section{HASIL DAN PEMBAHASAN}

Hasil penelitian menunjukkan bahwa semua data yang diperoleh baik itu observasi guru dan siswa, wawancara membuktikan bahwa dengan adanya penggunaan media pembelajaran information and communication technologies (ICT) dapat membuat siswa termotivasi dan hasil belajarnya menjadi baik selain itu juga dapat menjadi suatu acuan bahwa media ICT bersifat positif. Hasil belajar siswa dibuktikannya dengan adanya peningkatan dari nilai siswa yang diberikan oleh guru kelas kepada peneliti.

Sesuai dengan hasil penelitian yang diperoleh dari data analisis dan diaplikasikan dengan teori yang ada. Analisis data penelitian disesuaikan dengan rumusan masalah senelitian sebagai berikut:

\section{Penggunaan media pembelajaran} information and communiction technologies (ICT) dalam meningkatkan hasil belajar mata pelajaran IPS pada materi keragaman kenampakan alam dan buatan di Indonesia pada siswa kelas V SD Joseph Khatulistiwa tahun pelajaran 2017/2018.
Menurut Arifin (2012:88) ICT adalah sebuah payung besar terminoligi yang mencakup seluruh peralatan teknis untuk memproses dan menyampaikan informasi. ICT mencakup dua aspek, yaitu teknoligi informasi dan teknologi komunikasi. Teknoligi informasi meliputi segala hal yang berkaitan dengan proses, penggunaan sebagai alat bantu, manipulasi, dan pengelolaan informasi. Sedangkan teknologi komunikasi adalah segala sesuatu yang berkaitan dengan penggunaan alat bantu untuk memproses dan mentrasfer data dari perangkat yang satu ke lainnya. Media pembelajaran ICT sebagai alat bantu guru dan siswa agar lebih aktif dalam proses belajar mengajar di dalam kelas khususnya pelajaran IPS materi keragaman kenampakan alam dan buatan di Indonesia.

Berdasarkan hasil penelitian dari alat pengumpul data berupa lembar observasi siswa pada siklus I dan siklus II di kelas V SD Joseph Khatulistiwa, terlihat perubahan peningkatan pada siswa dalam pembelajaran dengan menggunakan media pembelajaran ICT tersebut. Oleh sebab itu, penggunaan media pembelajaran ICT sangat membantu dalam proses belajar mengajar terutama dalam pembelajaran IPS materi keagaman kenampakan alam dan buatan di Indonesia 


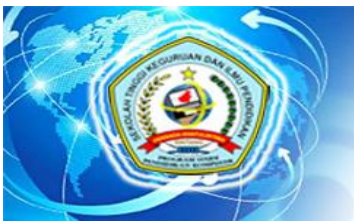

\section{BUEECH \\ Journal Education and Technology}

http://jurnal.stkippersada.ac.id/jurnal/index.php/jutech/index
E-ISSN.
1. Peningktan hasil belajar mata pelajaran IPS menggunakan mediapembelajaran information and communication technologies (ICT) pada materi keragaman kenampakan alam dan buatan di Indonesia pada siswa kelas V SD Joseph Khatulistiwa tahun pelajaran 2017/2018.

Hasil belajar merupakan kemampuan yang dimiliki seorang siswa dalam proses belajar di sekolah. Jika siswa hanya datang, duduk, dan diam saat proses pembelajaran, maka siswa akan dianggap tidak memiliki potensi. Menurut Purwanto (2010:45) hasil belajar merupakan perubahan yang mengakibatkan manusia berubah dalam sikap dan tingkah lakunya. Oleh sebab itu berdasarkan hasil belajar siswa yang diperoleh pada siklus I diperoleh dari 9 siswa yang mengikuti tes hanya 4 siswa yang tuntas dan tidak tuntas terdapat 5 siswa, rata-rata nilai sebesar 65,88 dengan ketuntasan klasikal 55,56\% tahap ini ditemukan hasil yang belum mencapai ketuntasan klasikal $85 \%$ hal ini terjadi karena siswa masih terlihat bingung dengan cara menggunakan media ICT, dengan demikian peneliti melanjutkan ke tahap berikutnya yaitu siklus ke II dengan harapan hasil belajar siswa meningkat dari 9 siswa yang mengikuti tes dan yang tidak tuntas hanya 1 siswa hal tersebut dikarenakan siswa mengalami keterbatasan menulis dan membaca, dengan demikian nilai rata-rata 85,89 dan ketuntasan klasikal 88,89\%. Sehingga dengan demikian ketuntasan hasil siswa pada siklus II dinyatakan berhasil.

Dari uraian di atas dapat disimpulkan bahwa penggunaan media pembelajaran information and communication technologies (ICT) dalam pembelajaran IPS pada materi keragaman kenampakan alam dan buatan di Indonesia dapat meningkatkan hasil belajar siswa. Selain itu, media pembelajaran ICT juga merupakan wujud dari kreatifitas guru di dalam melaksanakan pembelajaran di kelas.

1. Respon siswa mata pelajaran IPS menggunakan media information and communication technologies (ICT) pada materi keragaman kenampakan alam dan buatan di Indonesia pada siswa kelas V SD Joseph Khatulistiwa tahun pelajaran 2017/2018.

Dari hasil penelitian tindakan siklus I dan siklus II setelah peneliti melakukan wawancara untuk siswa, diperoleh hasil bahwa sebagian besar dari jumlah keseluruhan item pertanyaan siswa mengaku bahwa pembelajaran dengan menggunakan media pembelajaran information and communication technologies (ICT) sangat menyenangkan dan sangat membantu, karena selain dapat 


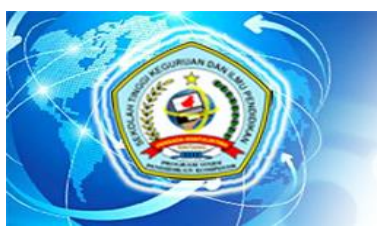

\section{8

membantu proses belajar mengajar, dalam pembelajaran materi yang diberikan guru sangat mudah di mengerti oleh siswa sehingga hasil belajar siswa pun meningkat.

Sedangkan hasil wawancara peneliti dengan guru kelas $\mathrm{V}$ tentang respon guru terhadap media yang digunakan mendapat respon positif dari guru, sehingga hasil belajar siswa meningkat. Dari uraian di atas dapat disimpulkan bahwa penggunaan media pembelajaran ICT pada materi keragaman kenampakan alam dan buatan di Indonesia dapat meningkatkan hasil belajar siswa.

\section{SIMPULAN}

Berdasarkan hasil belajar IPS dan hasil observasi terhadap penggunaan media pembelajaran information and communication technologies (ICT) untuk meningkatkan hasil belajar IPS siswa pada materi keragaman kenampakan alam dan buatan di Indonesia pada siswa kelas V SD Joseph Khatulistiwa tahun pelajaran 2017/2018. Maka dapat diambil kesimpulan sebagai berikut:

1. Pengguanan media pembelajaran ICT sangat efektif. Terbukti dari hasil observasi terhadap aktivitas guru dan siswa dapat dilihat bahwa siswa sangat aktif mempersiapkan diri untuk menerima pembelajaran, dapat mengikuti arahan guru, merespon saat guru bertanya mengenai materi yang disampaikan. Terlihat perubahan peningkatan pada siswa dalam pembelajaran dengan menggunakanmedia pembelajaran ICT tersebut. Sehingga siswa mampu memperoleh peningkatan hasil belajar yang memuaskan. Media pembelajaran ICT tersebut dapat meningkatkan hasil belajar siswa bila dilakukan dengan sungsuh-sungguh dan teliti.

2. Hasil belajar IPS pada siswa kelas V SD Joseph Khatulistiwa tahun pelajaran 2017/2018 mengalami peningkatan setelah pembelajaran dilakukan dengan menggunakan media pembelajaran ICT. Berdasarkan hasil belajar siswa yang diperoleh pada siklus I diperoleh 9 siswa yang mengikuti tes 5 siswa yang tuntas dan tidak tuntas terdapat 4 siswa, ratarata nilai sebesar 68,88 dengan ketuntasan dengan ketuntasan klasikal $55,56 \%$ tahap ini ditemukan hasil yang belum mencapai ketuntasan klasikl $85 \%$ hal ini terjadi karena siswa masih terlihat bingung dengan pembelajaran menggunakan media ICT dengan demikian peneliti melanjutkan ke tahap berikutnya yaitu siklus II dengan 
harapan hasil belajar siswa dapat mencapai ketuntasan yang diharapkan.

Pada siklus II hasil belajar siswa meningkat dari 9 siswa yang mengikuti tes hanya 1 siswa yang tidak tuntas, dengan nilai rata-rata 85,89 dan ketuntasan klasikal 88,89\%. Sehingga ketuntasan hasil belajar siswa pada siklus II dinyatakan berhasil. Dengan demikian penggunaan media ICT dalam pembelajaran sudah mengalami peningkatan dan indikator keberhasilan siswa sudah mencapai KKM.

3. Respon siswa terhadap media ICT pada materi keragaman kenampakan alam dan buatan di Indonesia pada siswa kelas V SD Joseph Khatulistiwa tahun pelajaran 2017/2018. Hasil dari respon siswa terhadap media yang digunakan dalam proses belajar sangat baik. Dari hasil data wawancara untuk siswa berdasarkan item pertanyaan siswa mengaku bahwa pembelajarandengan menggunakan media ICT sangat menyenangkan, karena selain menarik perhatian siswa untuk fokus dalam belajar pembelajaran materi yang diberikan guru mudah di mengerti oleh siswa. Sehingga hasil belajar siswa meningkat. Sedangkan hasil wawancara peneliti dengan guru kelas yang sekaligus guru mata pelajaran IPS tentang respon guru terhadap media yang digunakan mendapat respon yang positif dari guru, sehingga hasil belajar siswa meningkat. Dari uraian di atas dapat disimpulkan bahwa media pembelajaran ICT dalam pembelajaran IPS pada materi keragaman kenampakan alam dan buatan di Indonesia dapat meningkatkan hasil belajar siswa. 


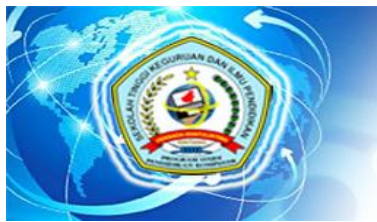

\section{DAFTAR RUJUKAN}

Ahmad. 2012. Perencanaan Pembelajaran.Bandung: Bumi Aksara

Arifin. 2012. Pengembangan pembelajaran aktif menggunakan ICT. Yogyakrta:PT. Skripta Media Creative.

Arikunto, S. 2013. Dasar-dasar evaluasi pendidikan (Edisi Revisi). Jakarta:Bumi Aksara.

Arsyad. 2013. Media pembelajaran aktif. Jakarta:Grafindo Persada.

Kunandar. 2008. Penelitian tindakan kelas. Bandung:Alfabeta.
Purwanto. 2012. Evaluasi dan hasil belajar. Yogyakarta: Pustaka Belajar

Sudjana. 2016. Penilaian hasil dan proses belajar mengajar. Bandung: Remaja Rosdakarya.

Sugiyono. 2011. Metode penelitian kuantitatif, kualitatif, dan $R \& D$. Bandung: Alfabeta.

Sugiyono. 2013. Metode penelitian kuantitatif, kualitatif, dan $R \& D$. Bandung: Alfabeta.

Sukardi. 2013. Metodoligi Penelitian Tindakan.Bandung: PT Bumi Aksara

Sutikno. 2009. Belajar dan Pembelajaran. Bandung. Prospect. 